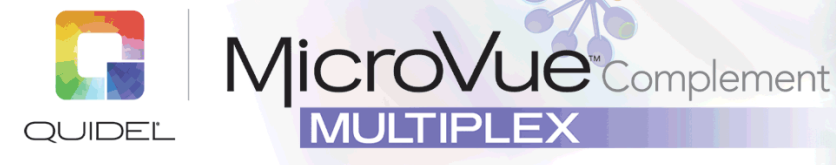

9 Analytes $=$ Comprehensive Analysis $\mathrm{Ba}, \mathrm{Bb}, \mathrm{C} 3 \mathrm{a}, \mathrm{C} 4 \mathrm{a}, \mathrm{C} 4 \mathrm{~d}, \mathrm{C} 5 \mathrm{a}$ SC5b-9, Factor $\mathrm{H}$, Factor 1

\section{A A The Journal of Immunology}

This information is current as of April 30, 2019.
First Identification of a Chemotactic Receptor in an Invertebrate Species: Structural and Functional Characterization of Ciona intestinalis C3a Receptor

Daniela Melillo, Georgia Sfyroera, Rosaria De Santis, Rita Graziano, Rita Marino, John D. Lambris and Maria Rosaria Pinto

J Immunol 2006; 177:4132-4140; ;

doi: 10.4049/jimmunol.177.6.4132

http://www.jimmunol.org/content/177/6/4132

References This article cites $\mathbf{3 6}$ articles, 13 of which you can access for free at: http://www.jimmunol.org/content/177/6/4132.full\#ref-list-1

Why The JI? Submit online.

- Rapid Reviews! 30 days* from submission to initial decision

- No Triage! Every submission reviewed by practicing scientists

- Fast Publication! 4 weeks from acceptance to publication

*average

Subscription Information about subscribing to The Journal of Immunology is online at: http://jimmunol.org/subscription

Permissions Submit copyright permission requests at: http://www.aai.org/About/Publications/JI/copyright.html

Email Alerts Receive free email-alerts when new articles cite this article. Sign up at: http://jimmunol.org/alerts 
The Journal of Immunology

\title{
First Identification of a Chemotactic Receptor in an Invertebrate Species: Structural and Functional Characterization of Ciona intestinalis C3a Receptor
}

\author{
Daniela Melillo,* Georgia Sfyroera, ${ }^{*}$ Rosaria De Santis, ${ }^{*}$ Rita Graziano, ${ }^{\dagger}$ Rita Marino, ${ }^{\dagger}$ \\ John D. Lambris, ${ }^{1 *}$ and Maria Rosaria Pinto ${ }^{1 *}$
}

In mammals, the bioactive fragment $\mathrm{C} 3 \mathrm{a}$, released from $\mathrm{C} 3$ during complement activation, is a potent mediator of inflammatory reactions and exerts its functional activity through the specific binding to cell surface $G$ protein-coupled seven-transmembrane receptors. Recently, we demonstrated a Ciona intestinalis $\mathrm{C3a}$ (CiC3a)-mediated chemotaxis of hemocytes in the deuterostome invertebrate Ciona intestinalis and suggested an important role for this molecule in inflammatory processes. In the present work, we have cloned and characterized the receptor molecule involved in the CiC3a-mediated chemotaxis and studied its expression profile. The sequence, encoding a 95,394 Da seven-transmembrane domain protein, shows the highest sequence homology with mammalian C3aRs. Northern blot analysis revealed that the CiC3aR is expressed abundantly in the heart and neural complex and to a lesser extent in the ovaries, hemocytes, and larvae. Three polyclonal Abs raised in rabbits against peptides corresponding to CiC3aR regions of the first and second extracellular loop and of the third intracellular loop react specifically in Western blotting with a single band of 98-102 kDa in hemocyte protein extracts. Immunostaining performed on circulating hemocytes with the three specific Abs revealed that $\mathrm{CiC} 3 \mathrm{aR}$ is constitutively expressed only in hyaline and granular amoebocytes. In chemotaxis experiments, the Abs against the first and second extracellular loop inhibited directional migration of hemocytes toward the synthetic peptide reproducing the $\mathrm{CiC} 3 \mathrm{a} \mathrm{C}$-terminal sequence, thus providing the compelling evidence that $C$. intestinalis expresses a functional $\mathrm{C} 3 \mathrm{aR}$ homologous to the mammalian receptor. These findings further elucidate the evolutionary origin of the vertebrate complement-mediated proinflammatory process. The Journal of Immunology, 2006, 177: 4132-4140.

I $\mathrm{n}$ all vertebrates, local injuries to living tissues result in an inflammatory response, which represents an important first line of defense, operating in tight association with both the innate and adaptive immune responses. In this context, the complement system plays a pivotal role. In fact, its activation results in the generation of the bioactive fragments, C3a and C5a, which are potent mediators of inflammation $(1,2)$.

In particular, the anaphylatoxin $\mathrm{C} 3 \mathrm{a}$ is a 74- to 78-aa peptide generated by proteolytic cleavage of the $\mathrm{N}$-terminal end of the $\mathrm{C} 3$ $\alpha$-chain during the activation of either the classical, lectin, or alternative pathways of the complement system $(3,4)$. Our knowledge of the functional and structural features of this anaphylatoxin comes mainly from studies of the mammalian C3a molecules, which possess various immunomodulatory and proinflammatory activities $(2,5,6)$. Most of the biological effects of $\mathrm{C} 3 \mathrm{a}$, including the recruitment and activation of leukocytes and other effector cells at an inflammatory site, are elicited via specific binding to cell surface $\mathrm{G}$ protein-coupled seven-transmembrane receptor(s) $(2,7)$ belonging to the rhodopsin family. The $\mathrm{C} 3$ a receptor $(\mathrm{C} 3 \mathrm{aR})$ has

*Laboratory of Cell Biology and ${ }^{\dagger}$ Gene Expression Service, Stazione Zoologica "Anton Dohrn," Napoli, Italy; and "Protein Chemistry Laboratory, Department of Pathology and Laboratory Medicine, University of Pennsylvania, Philadelphia, PA 19104

Received for publication April 24, 2006. Accepted for publication June 29, 2006.

The costs of publication of this article were defrayed in part by the payment of page charges. This article must therefore be hereby marked advertisement in accordance with 18 U.S.C. Section 1734 solely to indicate this fact.

${ }^{1}$ Address correspondence and reprint requests to Dr. Maria Rosaria, Stazione Zoologica “Anton Dohrn," Villa Comunale, 80121 Napoli, Italy; E-mail address: pinto@szn.it or Dr. John D. Lambris, Protein Chemistry Laboratory, Department of Pathology and Laboratory Medicine, School of Medicine, University of Pennsylvania, 401 Stellar Chance, Philadelphia, PA 19104; E-mail address: lambris@mail.med.upenn.edu been cloned from different mammalian species (8-14), and its functional characterization has been conducted mainly in humans and mice $(2,7)$. A feature common to all the mammalian C3aRs is their broad pattern of tissue distribution, which includes lymphoid organs $(8-14)$.

The most remarkable feature of mammalian C3aRs is the presence of an unusually large second extracellular loop (EL) ${ }^{2}$ of $\sim 175$ aa between the fourth and fifth transmembrane domains, exhibiting low sequence homology among species (7). The existence of this unique structural feature among the $\mathrm{G}$ protein-coupled receptors has suggested a special role for this loop in ligand binding. Indeed, the analysis of chimeric and deletion mutants of the human $\mathrm{C} 3 \mathrm{aR}$ has established that as much as $65 \%$ of the second EL sequence (aa 198-308) can be removed without affecting C3a binding or the calcium response (15). This analysis has also suggested a two-site C3a-C3aR interaction model similar to that established for C5a-C5aR. A primary effector site on the receptor interacts with the $\mathrm{C} 3 \mathrm{a} \mathrm{C}$-terminal sequence GLAR, whereas the anionic residues near the $\mathrm{N}$ and $\mathrm{C}$ termini of the $\mathrm{C} 3 \mathrm{aR}$ second $\mathrm{EL}$ constitute a secondary interaction site with the cationic residues in the C-terminal helical region of C3a (15). More recently, it has been demonstrated that sulfation of $\mathrm{Tyr}^{174}$ of human $\mathrm{C} 3 \mathrm{aR}$ is essential for $\mathrm{C} 3 \mathrm{a}$ binding (16). Following ligand binding, $\mathrm{C} 3 \mathrm{aR}$ is internalized within minutes, and the phosphorylation of cytosolic C-terminal Ser and Thr residues seems to play a crucial role in this process $(17,18)$.

\footnotetext{
${ }^{2}$ Abbreviations used in this paper: EL, extracellular loop; CiC3a, C. intestinalis C3a; JTT, Jones-Taylor-Thornton; IL, intracellular loop.
} 
Whereas the mammalian inflammatory pathway of the complement system is well characterized at both the molecular and functional levels, little information is available about its structure, function, and evolution in nonmammalian vertebrates and invertebrates (19). Very recently, a trout cDNA has been cloned that encodes a 364-aa molecule, which shows a high degree of sequence homology and a strong phylogenetic relationship with mammalian C3aRs. However this C3a-like receptor was found to lack a significant portion of the large second EL characterizing the mammalian C3aRs (20). C3-like genes have been also identified in different species of invertebrates (21), and in limited instances, C3-mediated functions have been reported in these organisms (22-25).

Using the ascidian Ciona intestinalis as a model, we have previously shown the presence of an inflammatory effector pathway of the complement system in deuterostome invertebrates (26). In fact, we have demonstrated a specific chemotactic activity exerted on Ciona hemocytes by the cell-free hemolymph or the recombinant Ciona C3a. As is true for mammalian C3a, the chemotactic activity of $C$. intestinalis $\mathrm{C} 3 \mathrm{a}$ (CiC3a) was localized to the $\mathrm{C}$ terminus, but the terminal Arg was not critical for the activity. The C3a-mediated chemotaxis was inhibited by pretreatment of the cells with pertussis toxin, suggesting that the receptor molecule mediating the chemotactic effect is $G$ protein coupled (26).

To clarify the molecular mechanisms underlying the complement-mediated proinflammatory processes in invertebrates, we have now identified and sequenced a $C i C 3 a R$ gene that exhibits a wide pattern of tissue expression. Three polyclonal Abs raised against peptides reproducing different portions of the deduced amino acid sequence of this receptor have been used in chemotaxis experiments, Western blot analysis, and immunostaining of circulating hemocytes. The results of these experiments demonstrate for the first time the presence and the functional activity of a C3aR in an invertebrate species.

\section{Materials and Methods Hemocyte preparation}

Specimens of $C$. intestinalis were collected in the Gulf of Napoli and maintained in circulating seawater until use. The hemolymph was collected from the perivisceral cavity with a syringe.

To prepare hemocytes, hemolymph was immediately diluted $1 / 2$ with ice-cold artificial seawater, $\mathrm{Ca}^{2+}$ and $\mathrm{Mg}^{2+}$-free, containing $10 \mathrm{mM}$ EDTA (pH 7.4). Following centrifugation at $500 \times g$ for $5 \mathrm{~min}$ at $4^{\circ} \mathrm{C}$, hemocytes were resuspended in marine solution: $0.45 \mathrm{M} \mathrm{NaCl}, 26 \mathrm{mM} \mathrm{MgCl} 2,11 \mathrm{mM}$ $\mathrm{KCl}$, and $12 \mathrm{mM} \mathrm{CaCl}_{2}(\mathrm{pH}$ 7.4). The cell number was evaluated in a Neubauer chamber, and the volumes were adjusted to give a final concentration of $2.5 \times 10^{6}$ cells $/ \mathrm{ml}$ for chemotaxis assays.

\section{RNA isolation}

Total RNA was prepared from hemocyte pellet, ovary, heart, neural complex, and larval stage of Ciona using the kit SV Total RNA isolation system (Promega), according to the manufacturer's instruction. The neural complex included the adult Ciona single cerebral ganglion and the associated neural gland.

\section{RT-PCR amplification}

Oligo(dT)-primed single-stranded cDNA was synthesized from hemocyte RNA with a RT-PCR kit (Invitrogen Life Technologies), according to the manufacturer's instruction. The cDNA was PCR amplified using two specific primers (sense primer, $5^{\prime}$-GATTCAAATCGCCGCAACAGA-3', and antisense primer, 5'-ATGAAGCTCGGCAGTGCGCATGA-3'), designed on the basis of the 381-nt gene model sequence ci0100141062, Scaffold_455:55844-58678, of the C. intestinalis genome, version 1.0, provided by JGI (〈www.jgi.doe.gov/ $\rangle)$. The conditions used were as follows: $94^{\circ} \mathrm{C}$ for $15 \mathrm{~s}, 56.3^{\circ} \mathrm{C}$ for $30 \mathrm{~s}$, and $72^{\circ} \mathrm{C}$ for $1 \mathrm{~min}$. A single band of the expected size ( $333 \mathrm{bp}$ ) was detected. This product was cloned into the pCRII-TOPO vector (Invitrogen Life Technologies) and verified by sequencing.

\section{$5^{\prime}-$ and $3^{\prime}-R A C E S$}

To determine sequences at the $5^{\prime}$ - and $3^{\prime}$-ends of the CiC3aR mRNA, RACE assays were conducted using the $5^{\prime}$ - and $3^{\prime}$-RACE system (Invitrogen Life Technologies). To amplify the $3^{\prime}$-end, an oligo(dT) containing adapter primer was used for the first-strand cDNA synthesis of hemocyte total RNA. The cDNA amplification was performed using the abridged universal amplification primer (AUAP) and a gene-specific primer $\left(5^{\prime}\right.$ GATTCAAATCGCCGCAACAGA-3') designed according to the sequence of the 333-bp product. The PCR product that hybridized with an oligo (5'-TGATTTCCACACGGCAACGC-3') located at the $3^{\prime}$-end of the gene-specific oligo was cloned and sequenced.

To amplify the $5^{\prime}$-end, the antisense oligo $5^{\prime}$-GGTTGTTGTCAGAT GCGTGTT- $3^{\prime}$ designed according to the sequence of the $3^{\prime}$-RACE product was used for the first-strand cDNA synthesis of total RNA. After tailing, the purified single-strand cDNA was amplified by PCR using the anchor primer and the nested gene-specific oligo (5'-ATGAAGCTCGGCAGT GCGCATGA-3'). The PCR product that hybridized with the oligo $\left(5^{\prime}-\right.$ TGATTTCCACACGGCAACGC-3') located at the $5^{\prime}$-end of the nested oligo was cloned and sequenced.

The $5^{\prime}$ - and $3^{\prime}$-RACE products were cloned into the pCRII-TOPO vector (Invitrogen Life Technologies).

\section{Southern blot analysis}

Genomic DNA was isolated from Ciona sperm according to standard protocols (27). The DNA (4 $\mu \mathrm{g})$ was digested to completion with the restriction enzymes, EcoRI and HindIII, separated on a $0.8 \%$ agarose gel, and transferred to a Hybond- $\mathrm{N}^{+}$nylon membrane (Amersham Biosciences) in $20 \times$ SSC. The transferred DNA was UV cross-linked at $120 \mathrm{~mJ} / \mathrm{cm}^{2}$, prehybridized in a buffer composed of $5 \times$ SSC, $5 \times$ Denhardt's solution, 5 mM EDTA, $0.5 \%$ SDS, $200 \mu \mathrm{g} / \mathrm{ml}$ salmon sperm, and $50 \mathrm{mM}$ sodium phosphate ( $\mathrm{pH} 7.2$ ), then hybridized for $16 \mathrm{~h}$ at $60^{\circ} \mathrm{C}$ in the same buffer containing the $843-\mathrm{bp}^{32} \mathrm{P}$-labeled random-primed probe (28), corresponding to the 597-1439 region of the coding sequence. PCR analysis of genomic DNA indicated that this fragment, out of the several amplified, did not contain introns. At the end of the hybridization time, the membranes were briefly rinsed in $2 \times \mathrm{SSC}$ with $0.1 \%$ SDS at room temperature and then washed in $2 \times$ SSC with $0.1 \%$ SDS for $15 \mathrm{~min}$ at room temperature and $15 \mathrm{~min}$ at $60^{\circ} \mathrm{C}$. The blot was exposed in an autoradiography cassette to the $\mathrm{x}$-ray BioMax MS film (Eastman Kodak) at $-80^{\circ} \mathrm{C}$.

\section{Northern blot analysis}

Total RNA (6 $\mu \mathrm{g} / \mathrm{lane})$ was electrophoresed on a $1.2 \%$ agarose/formaldehyde gel and transferred to a nylon filter (Hybond $\mathrm{N}^{+}$; Amersham Biosciences) using $10 \times$ SSC as the transferring buffer. The transferred RNA was UV cross-linked at $120 \mathrm{~mJ} / \mathrm{cm}^{2}$, prehybridized in $5 \times \mathrm{SSC}$ with $5 \times$ Denhardt's solution, $5 \mathrm{mM}$ EDTA, $0.5 \%$ SDS, $200 \mu \mathrm{g} / \mathrm{ml}$ salmon sperm, and $50 \mathrm{mM}$ sodium phosphate ( $\mathrm{pH} 7.2)$, and hybridized for $16 \mathrm{~h}$ at $60^{\circ} \mathrm{C}$ in the same buffer containing the $747-\mathrm{bp}{ }^{32} \mathrm{P}$-labeled probe, corresponding to the 126-872 region of the coding sequence. Labeling of the probe, washing of the filter, and exposure to the film were conducted as described for the Southern blot analysis. The RNA ladder used as a marker, of 0.24-9.5 $\mathrm{kb}$, was from Invitrogen Life Technologies.

\section{Determination and analysis of DNA sequences}

Sequences were determined for both strands using vector- or gene-specific primers. Sequence reactions were obtained with the BigDye Terminator Cycle Sequencing technology (Applied Biosystems) and purified by automation using the Millipore Montage $\mathrm{SEQ}_{96}$ Sequencing Reaction Cleanup kit (Millipore) and a robotic station Biomek FX (Beckman Coulter). Products were analyzed on an Automated Capillary Electrophoresis Sequencer 3730 DNA Analyzer (Applied Biosystems).

cDNA sequence analysis was routinely performed by running a basic local alignment search tool of the GenBank database.

The deduced amino acid sequences of $\mathrm{CiC} 3 \mathrm{a}$ and $\mathrm{C} 3 \mathrm{a}$ receptors from different vertebrate species were aligned using the Clustal X 1.8 program (29), and the resulting alignment was corrected manually.

\section{Phylogenetic analysis}

To construct a phylogenetic tree, a data set including $\mathrm{CiC} 3 \mathrm{aR}$ and selected anaphylatoxin receptor amino acid sequences, aligned with the program Clustal X (29), was used. The CiC3aR amino acid residue insertion in the third cytoplasmic loop and the elongation of the carboxyl-terminal tail were not considered in the data set. The phylogenetic relationships among related sequences were inferred by the maximum likelihood method implemented in PHY-ML software (30). The Jones-Taylor-Thornton (JTT) substitution model (31), with gamma-distributed rates, was selected among 
alternative models (see Table I) using Tree-Puzzle software (32). The estimated value of the gamma distribution parameter $\alpha$ was $1.11 \pm 0.08$. The tree topology was reconstructed by applying the quartet puzzling maximum likelihood method implemented in Tree-Puzzle.

\section{Peptide synthesis and Ab production}

The 17-aa peptide, CiC3aR ${ }^{65-81}$ (HELPTEPTLQANAEPPP), the 17-aa peptide, CiC3aR $228-244$ (DPMYEEYQELYTDDIYG), and the 15-aa peptide, CiC3aR ${ }^{398-412}$ (LRRSLRKKARDRGTG), representing part of the $\mathrm{CiC} 3 \mathrm{aR}$-deduced amino acid sequence and located in the area of the presumptive first and second ELs and the third intracellular loop (IL), respectively, were synthesized using an Applied Biosystems 430A peptide synthesizer as described previously (33). The peptide was then coupled to OVA by the glutaraldehyde method and used for the immunization of rabbits to produce the anti-CiC3aR ${ }^{65-81}$ (anti-EL1) (Primm)-, antiCiC3aR ${ }^{228-244}$ (anti-EL2) (Primm)-, and anti-CiC3aR ${ }^{398-412}$ (anti-IL-3) (Cocalico Biologics)-specific Abs.

The three anti-peptide specific Abs were purified by affinity chromatography using the corresponding synthetic peptides coupled to cyanogen bromide-activated Sepharose 4B (Amersham Biosciences).

\section{Western blot analysis}

Hemocytes, collected as indicated above, were resuspended at $1.6 \times$ $10^{8} / \mathrm{ml}$ in sample buffer (60 mM Tris with $2 \%$ SDS, $10 \%$ 2-ME, $10 \%$ glycerol, and $0.01 \%$ bromophenol blue $(\mathrm{pH} 6.8)$ ) containing the protease inhibitor mixture Mini Complete (Roche Applied Science). Samples were homogenized by hand in a Potter-Elvejhem homogenizer with a Teflon pestle, boiled for $10 \mathrm{~min}$, and centrifuged at room temperature for $30 \mathrm{~min}$ at 13,400 rpm in a Mini Spin centrifuge (Eppendorf). The supernatant was recovered and stored as aliquots at $-20^{\circ} \mathrm{C}$. The reactivity of Ciona hemocyte proteins with the anti-EL1, anti-EL2, and anti-IL3 Abs was assessed by Western blotting analysis: $80 \mu \mathrm{g}$ of protein, corresponding to $4.8 \times 10^{6}$ hemocytes, was loaded onto a 7.5\% SDS-PAGE gel under reducing conditions. The proteins were then electroblotted onto a nitrocellulose membrane (Amersham Biosciences), and the $\mathrm{CiC} 3 \mathrm{aR}$ was detected using 10 $\mu \mathrm{g} / \mathrm{ml}$ of affinity-purified anti-EL1, anti-EL2, or anti-IL3 Ab. Nonspecific binding to the membrane was prevented by incubation in blocking buffer (PBS containing 5\% milk and $0.05 \%$ Tween 20). Bound polyclonal Abs were detected with a protein A-HRP conjugate (Bio-Rad), according to the manufacturer's instructions. All the incubation steps were performed for $1 \mathrm{~h}$ at room temperature, and the membranes were washed with PBS containing Tween $20(0.05 \%)$ between each incubation step. The proteins were detected using the ECL Plus kit (Amersham Biosciences). Protein determination assays were performed using a BCA kit (Sigma-Aldrich).

\section{Immunostaining of circulating hemocytes}

Hemocytes, collected as described above, were fixed for $30 \mathrm{~min}$ at room temperature in $4 \%$ paraformaldehyde with $0.5 \mathrm{M} \mathrm{NaCl}$ and $0.1 \mathrm{M}$ MOPS $(\mathrm{pH}$ 7.5). At the end of the incubation time, 100- $\mu$ l samples with $\sim 1.5 \times$ $10^{6}$ cells $/ \mathrm{ml}$ were applied onto Superfrost Plus slides (VWR International) by cytocentrifugation (Cytopro; Wescor) at room temperature for $6 \mathrm{~min}$ at $400 \mathrm{rpm}$. Following three washings of $5 \mathrm{~min}$ each with PBS containing $0.1 \%$ Tween 20 (PBT), slides were incubated for 20 min with $0.3 \%(\mathrm{v} / \mathrm{v})$ hydrogen peroxide in PBT and then washed again in PBT for 5 min, in PBT containing $10 \%$ normal goat serum for $10 \mathrm{~min}$, and three times for $5 \mathrm{~min}$

Table I. Comparison of maximum log-likelihood values for the anaphylatoxin receptor data set under different models of evolution ${ }^{a}$

\begin{tabular}{llc}
\hline \hline \multicolumn{1}{c}{ Model } & Rate & $\begin{array}{c}\text { Maximum } \\
\text { Likelihood }\left(\log _{\mathrm{L}}\right)\end{array}$ \\
\hline Blosum & Uniform & $-10,773.58$ \\
Blosum & Gamma & $-10,577.95$ \\
Dayhoff & Uniform & $-10,791.83$ \\
Dayhoff & Gamma & $-10,537.88$ \\
JTT & Uniform & $-10,694.96$ \\
JTT & Gamma & $-10,448.11$ \\
Variable time & Uniform & $-10,912.42$ \\
Variable time & Gamma & $-10,633.35$ \\
\hline
\end{tabular}

${ }^{a}$ Maximum likelihood estimates of anaphylatoxin receptor phylogeny under different models. Entries are: maximum log-likelihoods under the models in the first column, considering the rate of evolution of the sites distributed as a uniform or gamma distribution as indicated in the table. in PBT. The incubation with the affinity-purified anti-EL1, anti-EL2, or anti-IL3 was performed for $1 \mathrm{~h}$ at room temperature in a humidified chamber at protein concentrations of 15,45 , and $30 \mu \mathrm{g} / \mathrm{ml}$, respectively, in PBT containing 1\% BSA. The slides were immunostained using the Vectastain Elite ABC kit (Vector Laboratories) and the Sigma Fast Dab set (SigmaAldrich), according to the manufacturer's instructions. Controls were run in parallel with preimmune rabbit IgG at the same concentrations. Staining was observed under a Zeiss Axioskop microscope with Nomarski optics.

Immunofluorescence microscopy was performed using the same procedure as described above, omitting the hydrogen peroxide treatment. The immunostaining was conducted for $1 \mathrm{~h}$ with the affinity-purified fluorescein-labeled goat anti-rabbit IgG (Vector Laboratories) diluted 1/250, followed by two $30-$ min washes and an overnight wash with PBS.

\section{Chemotaxis assay}

Chemotaxis experiments with $C$. intestinalis hemocytes were performed in single Blind Well Chambers, model BW200L (Neuro Probe). Polycarbonate filters (13-mm diameter, $5.0-\mu \mathrm{m}$ pore size; Whatman) were used to separate the upper and lower wells. The lower well contained $200 \mu \mathrm{l}$ of 10 $\mu \mathrm{M}$ chemoattractant in the form of the carboxyl-terminal synthetic peptide CiC3a ${ }^{59-76}$ (IALARLNSGTRRQRVQGR). Hemocytes (300 $\mu 1,2.5 \times 10^{6}$ cells $/ \mathrm{ml}$ ) were added to the upper well and allowed to migrate for $2 \mathrm{~h}$ at $20^{\circ} \mathrm{C}$. At the end of the incubation time, the fluid in the upper chamber and the nonmigrated cells on the top surface of the filter were gently wiped off with a cotton swab. The number of cells that had migrated to the lower well was estimated by counting 16 randomly chosen fields in a hemocytometer, and their percentage of the total number of cells added to the chemotaxis chamber was calculated. Chemotaxis control experiments were conducted with two nonrelated peptides substituting the specific chemoattractants in the lower well

For each inhibition experiment using anti-EL1, anti-EL2, or anti-IL3 Abs, hemocytes were resuspended in Eppendorf test tubes at $2.5 \times 10^{6}$ cells $/ \mathrm{ml}$ in marine solution containing the $\mathrm{Abs}$ in a concentration range from 0.5 to $15 \mu \mathrm{g} / \mathrm{ml}$. Following a $20-\mathrm{min}$ incubation at $20^{\circ} \mathrm{C}, 300-\mu \mathrm{l}$ samples were moved to the upper well of the chemotaxis chambers, and the chemotaxis assay was run and evaluated as described above. Control chemotaxis inhibition experiments were run in parallel with the same amounts of the corresponding preimmune rabbit $\operatorname{IgG}$ or an affinity-purified $\mathrm{Ab}$ of unrelated specificity (anti-trout factor $\mathrm{H} \mathrm{Ab}$ ). The results of inhibition experiments are presented as the percentage of inhibition of cell migration and are expressed as the mean $\pm \mathrm{SD}$ of five independent experiments conducted in duplicate. A further control was also performed using the Ab-related peptides: the synthetic peptides used to raise rabbit Abs against the first and the second ELs were used in competition experiments in which the hemocytes were incubated with $5 \mu \mathrm{g} / \mathrm{ml}$ of the $\mathrm{Ab}$ in the presence of $0.06 \mu \mathrm{M}$ of the corresponding peptide, then used in chemotaxis experiments.

\section{Results}

\section{Identification and sequence analysis of the $\mathrm{CiC} 3 \mathrm{aR}$ gene}

To identify the CiC3aR gene, we conducted an in-depth search of the $C$. intestinalis genome web site (〈http://genome.jgipsf.org/ Ciona4/Ciona4.home.html $\rangle$ ) for sequences showing significant homology to mammalian C3aRs. We found only one homologous gene model (ci0100141062), located at the $3^{\prime}$-end of the scaffold 455 (55844-58678) and including three exons, for total of $381 \mathrm{bp}$. The analysis of the deduced amino acid sequence indicated that it includes the second, third, and fourth transmembrane domains, as well as a few amino acid residues of the presumptive second EL of a $\mathrm{G}$ protein-coupled seven-transmembrane receptor.

To verify the presence in Ciona hemocytes of transcripts reproducing the identified sequence, we prepared total RNA and synthesized single-strand cDNA, which was then PCR amplified using two specific primers designed on the basis of the gene model sequence. A single band of the predicted size (333 bp) was detected. This product was cloned, sequenced, and found to correspond to the gene model sequence. Because our search of the Ciona genome for scaffolds, including the $3^{\prime}$-terminal portion of this sequence, did not produce any results, we used $3^{\prime}$-RACE to determine the sequence of the $3^{\prime}$-end of the presumptive Ciona C3aR gene. We obtained a 2894-bp amplification product that allowed us to complete the $3^{\prime}$-end. A single cycle of $5^{\prime}$-RACE was conducted to 


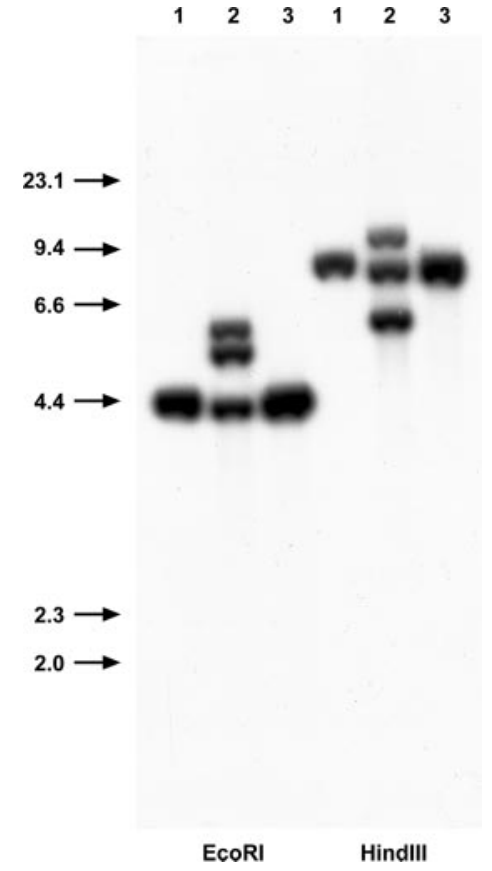

FIGURE 1. Southern blot analysis of CiC3aR. Four micrograms of sperm DNA isolated from three different animals was digested with EcoRI and HindIII endonucleases, run on an agarose gel, and transferred to a nylon membrane. Hybridization was conducted with a probe corresponding to the fragment 597-1439. Values on the left of the blot represent molecular mass markers in kilobases.

cover the $5^{\prime}$-end. The total transcript was 3071 bp (European Molecular Biology Laboratory database accession number AJ966353 located online ( $\langle$ www.ebi.ac.uk $/\rangle)$ and included a 52-bp 5'-untranslated region (UTR), a 2544-bp coding region with the initial methionine codon in the context of a canonical Kozac motif, and a 475-bp 3'-UTR, with two possible consecutive polyadenylation signals, at nt 3030 and 3037, and a poly(A) tail. A basic local alignment search tool analysis of this sequence in the Ciona genome, version 1.0, revealed that the $\mathrm{CiC} 3 \mathrm{aR}$ regions between the nt 1-750 and 1673-3053 were present in scaffolds 455 and 438, respectively, whereas the region between nt 751-1672 was not found in any scaffold. A further analysis conducted in the National Center for Biotechnology Information database revealed the presence of a 1536-bp C. intestinalis cDNA clone (ciht004g05; accession number AK174732) (34) corresponding to the 1534-3071 region of the presumptive $\mathrm{CiC} 3 \mathrm{aR}$.

To determine whether $\mathrm{CiC} 3 \mathrm{aR}$ was present as a single copy or in the form of multiple copies per haploid genome, Southern blot

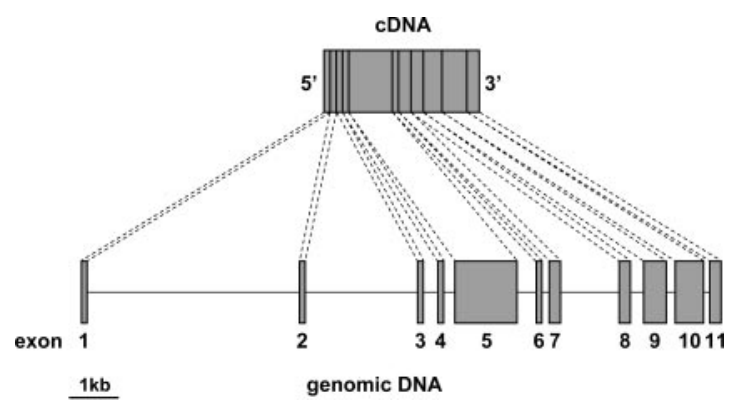

FIGURE 2. Genomic organization of the CiC3aR gene. Shown is a schematic representation of the gene encoding the CiC3aR. Exons are indicated by closed boxes. The lines connecting boxes represent the intervening introns. Scale bar: $1 \mathrm{~kb}$.

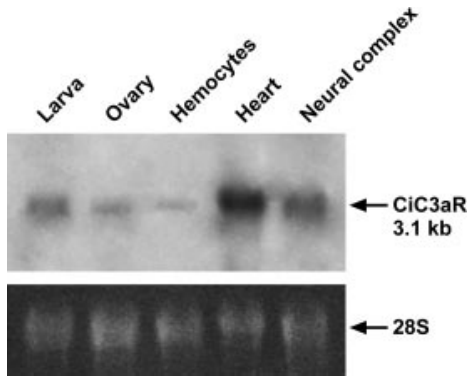

FIGURE 3. Tissue distribution of the $\mathrm{CiC} 3 \mathrm{aR}$ by Northern blot analysis. Total RNA ( $6 \mu \mathrm{g} / \mathrm{lane}$ ) from the indicated $C$. intestinalis tissues was electrophoresed, blotted onto a nylon membrane, and hybridized with a ${ }^{32} \mathrm{P}$-labeled 747-bp CiC3aR cDNA probe. The CiC3aR transcript was detected as a single band of $\sim 3.1 \mathrm{~kb}$ in all samples. The corresponding ethidium bromide-stained $28 \mathrm{~S}$ bands are shown in the lower part of the figure.

analysis of genomic DNA from three animals' sperm was performed. Each sample was digested with two endonucleases (EcoRI and HindIII), and the blot was hybridized with an 843-bp probe corresponding to the fragment 597-1439 of the coding sequence. Only a single hybridizing band was detected for the DNA of animals 1 and 3, allowing us to conclude that this gene is present as a single copy per haploid genome. Digestion with the same panel of restriction enzymes of the DNA from animal 2 revealed three bands per lane, reflecting the presence of allelic polymorphic sites within the gene (Fig. 1).

The alignment between the $\mathrm{CiC} 3 \mathrm{aR}$ transcript sequence and the Ciona genome assembly, version 2.0 (〈http://genome.jgi-psf.org/ Cioin2/Cioin2.home.html $\rangle$ ), released in March 2005, indicated that the entire $\mathrm{CiC} 3 \mathrm{aR}$ sequence was located on scaffold 187 (reverse strand) between nt 27,219 and 39,709. According to this alignment, 11 exons contribute to the gene structure (Fig. 2). The first exon encodes the $52 \mathrm{bp}$ of $5^{\prime}$-UTR and the first $96 \mathrm{bp}$ of the open reading frame, which spans from exon 1 to exon 10 ; the $475 \mathrm{bp}$ of the $3^{\prime}$-UTR are encoded by exons 10 and 11 . This genomic organization is significantly different from the mammalian $C 3 a R$ gene structure, which includes only two exons encoding the entire transcript, with the whole coding sequence contained on a single exon $(12,14)$.

Several tissues from adult animals and the larval stage were analyzed by Northern blot to evaluate the expression of the CiC $3 a R$ gene. A 747-bp ${ }^{32} \mathrm{P}$-labeled cDNA probe detected a single band of $\sim 3.1 \mathrm{~kb}$ in all tissues analyzed (Fig. 3), thus confirming the size of the total transcript ( $3071 \mathrm{bp}$ ) obtained by sequence analysis of the $3^{\prime}$ - and $5^{\prime}$-RACE products. In the heart, neural complex, and larvae, a broad band of the transcript was detected, whereas moderate levels were observed in ovary and circulating hemocytes.

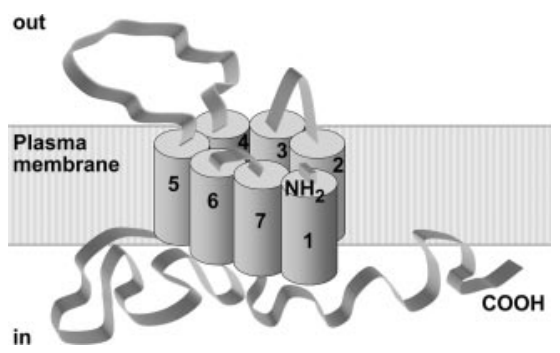

FIGURE 4. Schematic representation of the CiC3aR. The seven-transmembrane domains of the $\mathrm{CiC} 3 \mathrm{aR}$ are depicted as cylinders connected by ribbons representing the IL and EL. 
The open reading frame of 2,544 nt encodes a protein of 848 aa with a deduced molecular mass of 95,394 Da. Hydropathy analysis ( $\langle$ www.ch.embnet.org/software/TMPRED_form.html $\rangle$ ) of the predicted amino acid sequence of $\mathrm{CiC} 3 \mathrm{aR}$ suggested the presence of seven-transmembrane domains (as schematically represented in Fig. 4), a feature common to $\mathrm{G}$ protein-coupled receptors belonging to the rhodopsin family. The alignment of $\mathrm{CiC} 3 \mathrm{aR}$ with homologous sequences from other vertebrate species (Fig. 5) revealed a 276-aa insertion in the third cytoplasmic loop and a 105-aa elongation of the cytoplasmic tail. Not taking into account these regions, the Ciona sequence preceding the insertion shares $\sim 35 \%$ similarity with the other species, while the similarity is $\sim 45 \%$ for the region following the insertion.

The long hydrophilic region between the fourth and fifth transmembrane domain, EL2, a common feature of all C3a receptors, consisted of 162 aa in Ciona. Five of the seven identified $N$-glycosylation sequons ( $\langle$ www.cbs.dtu.dk/services/NetNGl yc/ $\rangle$ ) were localized to this loop.
Scanning the CiC3aR sequence for putative phosphorylation sites (35) revealed 43 serine, 15 threonine, and 11 tyrosine residues. Interestingly, the majority of serine (39 of 43) and threonine (12 of 15) residues were located in the third IL or the cytoplasmic tail. In the same regions, six sequences reproducing substrate motives of protein kinase $\mathrm{C},\left(\mathrm{R} / \mathrm{K}_{1-3}, \mathrm{X}_{2-0}\right) \mathrm{S} * / \mathrm{T}^{*}-\left(\mathrm{X}_{2-0}, \mathrm{R} / \mathrm{K}_{1-3}\right)(36)$, were found.

A phylogenetic tree was constructed based on the alignment of $\mathrm{CiC} 3 \mathrm{aR}$ with vertebrate $\mathrm{C} 3 \mathrm{aR}$ and $\mathrm{C} 5 \mathrm{aR}$ sequences. As shown in Fig. 6, CiC3aR did not cluster with any of the C3aR or C5aR clades, and its position suggests that it is the most basal of the anaphylatoxin receptors.

\section{Western blot analysis of circulating hemocytes}

To assess the presence of a $\mathrm{CiC} 3 \mathrm{aR}$ gene product in circulating hemocytes of Ciona, we examined the reactivity of the three specific Abs with hemocyte protein extracts by Western blotting. The

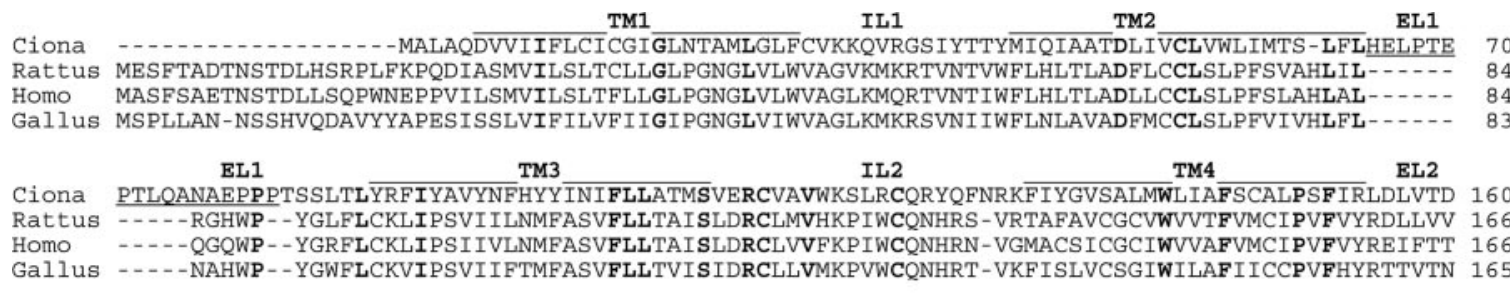

EL2

Ciona NINITRPANMKVAETHMYMKCY-EPLKHASD--NNLTY-VMDYDGISA-VDCYDIMQEDYLSLIDEIDTGMMDPMYEEYQELYTDDIYGD 245 Rattus DDYSVCGYNFDSSRAYDYWDYMYNSHLPEINPPDNSTGHVDDRTAPSSSVPARDL-WTATTALQSQTFHTSPEDPFSQDSA--SQQPHYG 253 Homo DNHNRCGYKFGLSSSLDYPDFYGDPLENRSLENIVQPPGEMNDRLDPSSFQTNDHPWTVPTVFQPQTFQRPSADSLPRGSARLTSQNLYS 256 Gallus GGKTECGYDFGDYEIPEYMDDSDPASGLLED-YSPLVPTVTYVNTIFAHQPT-DTYPDFQANSISTNKGIS---------TAAHLSHA 242

Ciona TGNITMLPELMQFVYQVTL-----PNGDNMTVVDHQIYFSLFHGIISHIH----NKSKKEPLGGICDPRLNKDAKIYN-IIVNLIIG $\overline{\text { FF }} 324$ Rattus GKPPTVLIATIPG-GFPVEDHKSNTL--NTGAFLSAHTEPSLTASSSPLYA----HDFPDDY-FDQLMYGNHAWTPQVAITISRLVVGFL 335 Homo NVFKPADVVSPKIPSGFPIEDHETSPLDNSDAFLSTHLKLFPSASSNSFYESELPOGFODYYNLGOFTDDDOVPTPLVAITITRLVVGFL 346 Gallus TVDVNSLLNSSAYPDIRLLESESDLPH--TSLPVPSNNDFDLKLLDPPLDL-_-_--ADFDSVFGDNDYAVSLPLIV-ITITRAVFGFI 322 TM5 IL3

Ciona IPFLAILISYVSIAHMIRVRALDRMENDCDVIESESTLGRRMSDFLRQFVSGGGPVKNVGESTPPYNKGSSPLLRRSLRKKARDRGTGLE 414 Rattus VPFFIMITCYSLIV--FRMRKT $\ldots \ldots$ Homo LPSVIMIACYSFIV--FRMQRG Gallus LPFSIVAACYAFIA--FRMRAS-

IL3

Ciona GSEVKSSRDDVVKPPVVRREEKPVVRDAGVDRRPRLSSFSHPTHSRRTSGGSASSAESFQTDQTSLHAATPSPGVRLSAPIFVHDKTPVQ 504

Rattus -

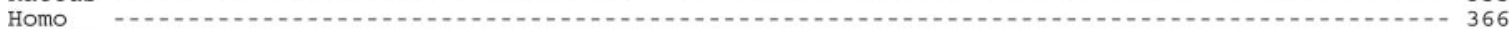
Gallus

IL3

Ciona RASSTETPTHPRSPPTRRWSSETLRSPHEASPPVLDETERLYDRVDDVTMAKPTSPPSGDSTQELFHGSYARLYSQKPDARPRYQRQAST 594

Rattus Homo Gallus 13 TM6

EL3 TM7

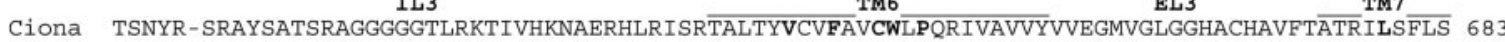
Rattus - - NLTKSRNKT- Homo - -RFAKSQSKT- Gallus --NYRKPQNKM-

TM7

CT

Ciona VLLNPIVYAMTQREIRHLLRRKLAGMCKCIHPGRESNPDPQNRDVNVSFANARRDFSVVADHNITSDEIFMKRERHARNKERWSRLMHRL 773

Rattus SCFNPFLYALLGKDFRKKAROSVKGILEAAFSEELTHSTSCTQDKAPSKRNHMSTDV $\ldots \ldots$

Homo SCFNPFLYALLGKDFRKKARQSIQGILEAAFSEELTRSTHCPSNNVI SERNSTTV $\ldots \ldots$

Gallus SCINPLLYVFVGRDFRAKARQSLQGVLERVFTEEPTCSTPYSLDK--SKTSKDKDISTTV

CT

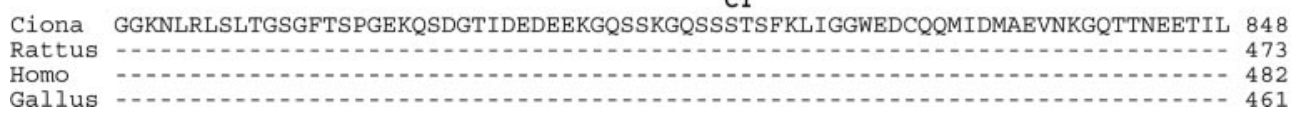

FIGURE 5. Alignment of the $\mathrm{CiC} 3 \mathrm{aR}$ amino acid sequence with $\mathrm{C} 3 \mathrm{aR}$ from other species. The deduced amino acid sequence of CiC $3 \mathrm{aR}$ was aligned with rat, human, and chicken $\mathrm{C} 3 \mathrm{aR}$ sequences, using the Clustal X (1.8) program, with adjustments made by hand. Identical residues in all sequences are shown in bold. The seven-putative transmembrane (TM) domains are overlined. ELs and ILs and the cytoplasmic tail are indicated by EL, IL, and CT, respectively. The three underlined sequences correspond to the synthetic peptides $\mathrm{CiC}_{\mathrm{a}} \mathrm{aR}^{65-81}, \mathrm{CiC} \mathrm{aR}^{228-244}$, and $\mathrm{CiC} 3 \mathrm{aR}{ }^{398-412}$ used as $\mathrm{Ags}^{2}$ to produce specific anti-CiC3aR Abs. Accession numbers: Ciona intestinalis, AJ966353; Rattus rattus, AAC40071; Homo sapiens, CAA97504; and Gallus gallus, CAG32407. 


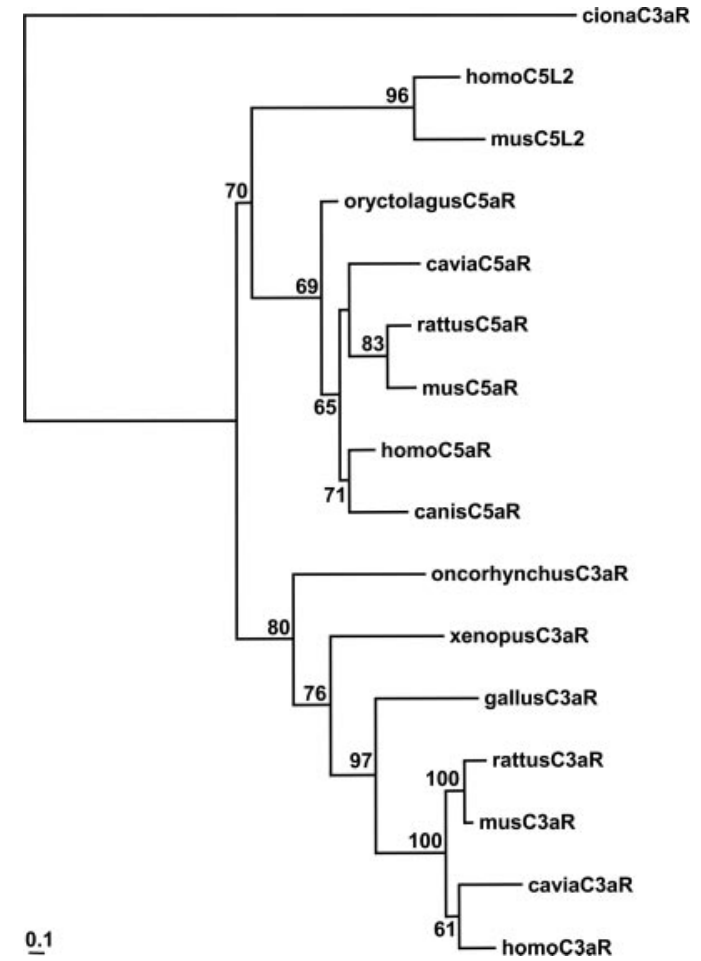

FIGURE 6. Phylogenetic tree of $\mathrm{CiC} 3 \mathrm{aR}$ and other anaphylatoxin receptor amino acid sequences. The tree was inferred by the maximum likelihood method as described in Materials and Methods. Bootstrap values (percentage of 1000 replicates) are given at the nodes. Accession numbers: Homo sapiens C5L2, BAA95414; Mus musculus C5L2, BAC35303; $H$. sapiens C5aR, NP_001727; Oryctolagus cuniculus C5AR, Q9TUE1; Canis familiaris C5aR, P30992; Cavia porcellus C5aR, O70129; Rattus norvegicus C5aR, NP_446071; M. musculus C5aR, AAB97774; R. norvegicus C3aR, AAC40071; M. musculus C3aR, AAH03728; H. sapiens C3aR, AAH20742; C. porcellus C3aR, O88680; Gallus gallus C3aR, CAG32407; Oncorhynchus mykiss C3aR, CAE83615; and C. intestinalis C3aR, AJ966353. The scale bar represents the expected numbers of amino acid replacements per site.

three affinity-purified Abs, anti-EL1, anti-EL2, and anti-IL3, reacted with the same protein band, which exhibited an apparent relative molecular mass of 98-102 kDa under reducing conditions (Fig. 7, $A-C$ ). The electrophoretic pattern of the hemocyte protein extract after Coomassie brilliant blue staining is shown in Fig. $7 D$. Glycosylation or other posttranslational modifications could account for the slight difference between the deduced $(95,394 \mathrm{Da})$ and the SDS-PAGE-calculated $(\sim 100 \mathrm{kDa})$ molecular size of $\mathrm{CiC} 3 \mathrm{aR}$.

\section{Hemocyte immunostaining}

To determine which blood cell types express CiC3aR, circulating hemocytes were immunostained with the affinity-purified antiEL1, anti-EL2, and anti-IL3 Abs. Staining of hemocytes revealed identical expression patterns for the three Abs. A clear staining was detected exclusively on the majority of hemocytes identified as granular and hyaline amoebocytes, according to the classification scheme of Rowley et al. (37). In Fig. 8A, immunostaining performed with the affinity-purified anti-IL3 Ab and the DAB substrate is shown. The cytoplasm of the granular and hyaline amoebocytes is characterized by the presence of granules that often appeared intensely stained. The cell types classified as vacuolated cells were never stained.

To extend the analysis of $\mathrm{CiC} 3 \mathrm{aR}$ expression pattern, immunofluorescence experiments were conducted using the affinity-puri-

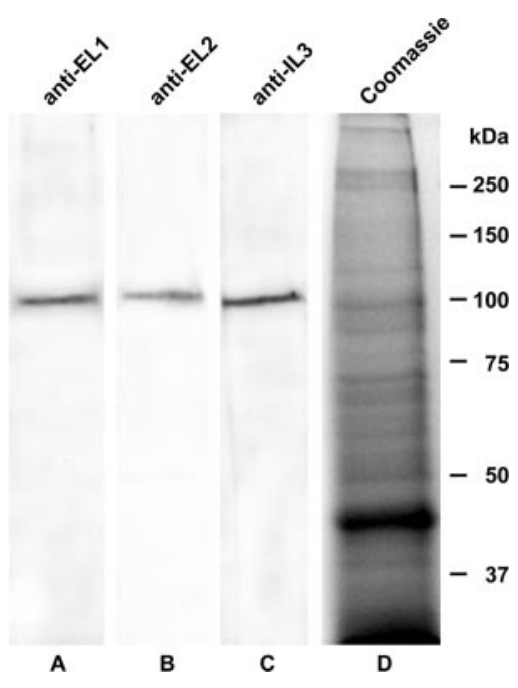

FIGURE 7. Reactivity of anti-peptide Abs with $C$. intestinalis hemocyte proteins. Proteins extracted from Ciona hemocytes ( $80 \mu \mathrm{g} / \mathrm{lane})$ were subjected to electrophoresis on a 7.5\% SDS polyacrylamide gel under reducing conditions, blotted onto nitrocellulose membranes, and then probed with anti-EL1 $(A)$, anti-EL2 $(B)$, and anti-IL3 $(C)$ affinity-purified Abs, followed by HRP-conjugated protein A and ECL. $D$, The Coomassie brilliant bluestained gel. The mobility of the molecular mass markers is shown on the right.

fied Abs and a fluorescein-conjugated secondary Ab. These experiments clearly indicated that $\mathrm{CiC} 3 \mathrm{aR}$ is expressed not only in the cytoplasm but also on the cell surface of both granular and hyaline amoebocytes (Fig. 8, $C-F$ ).

No staining was observed when control immunocytochemical reactions were performed using the IgGs from the preimmune rabbit sera (Fig. 8, $B, G$, and $H$ ).

\section{Inhibition of hemocyte chemotaxis by specific Abs}

To provide conclusive evidence that the identified and sequenced presumptive $C 3 a R$ gene encoded the CiC $3 \mathrm{aR}$, we performed chemotaxis experiments using the three polyclonal Abs, anti-EL1, anti-EL2, and anti-IL3, raised against the synthetic peptides $\mathrm{CiC} 3 \mathrm{aR}^{65-81}$, $\mathrm{CiC} 3 \mathrm{aR}^{228-244}$, and $\mathrm{CiC} 3 \mathrm{aR}^{398-412}$, representing deduced amino acid sequences in the first and second ELs and the third IL, respectively. We tested the ability of the affinity-purified Abs against the extracellular portions to inhibit the hemocyte chemotaxis elicited by the $\mathrm{C} 3 \mathrm{a}^{59-76}$ synthetic peptide. We previously demonstrated that this peptide representing the Ciona $\mathrm{C} 3 \mathrm{a} \mathrm{C}$ terminus is able to promote specific hemocyte chemotaxis in a dosedependent manner (26). In these experiments, we used as negative control the $\mathrm{Ab}$ directed against the cytoplasmic loop. Preincubation of the hemocytes with the anti-EL Abs (anti-EL1 and antiEL2) almost completely ( $>90 \%)$ inhibited their migration to the lower well of the chemotaxis chamber containing the chemoattractant peptide (Fig. 9). In contrast, preincubation of the hemocytes with the anti-cytoplasmic loop Ab (anti-IL3) had no inhibitory effect. The anti-EL1 and anti-EL2 Abs inhibited chemotaxis in a dose-dependent manner and produced 50\% inhibition at concentrations of 1.2 and $3.7 \mu \mathrm{g} / \mathrm{ml}$, respectively. Control experiments were run in parallel using either the preimmune polyclonal rabbit $\mathrm{IgG}$ or an affinity-purified polyclonal anti-trout factor $\mathrm{H}$; both had no inhibitory effect. A further control was performed using the Ab-related peptides in competition experiments. When the hemocytes were incubated with the $\mathrm{Ab}$ in the presence of the corresponding peptides, the inhibitory activity was completely abolished, thus demonstrating the specificity of the $\mathrm{Ab}$ recognition (data not shown). 

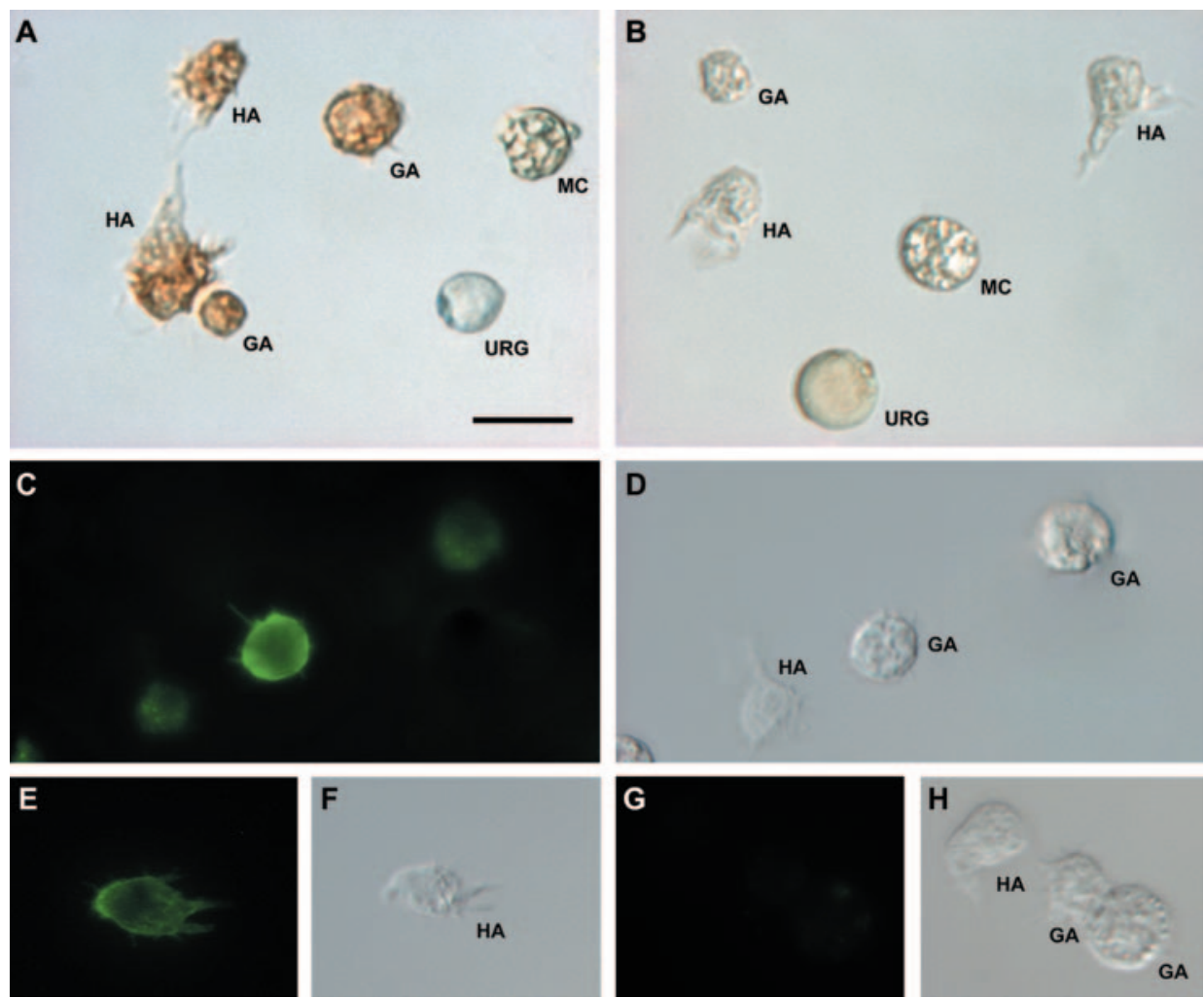

FIGURE 8. Immunostaining of $C$. intestinalis hemocytes. Circulating hemocytes were tested for the presence of CiC $3 \mathrm{aR}$ with the affinity purified anti-EL1, anti-EL2, or anti-IL3 Abs. A, The immunostaining reaction performed with the affinity-purified anti-IL3 Ab, using diaminobenzidine as a substrate. Staining revealed the intracellular localization of CiC3aR Ags in hyaline amoebocytes and granular amoebocytes. No labeling was detectable in morula cells and univacuolar refractile granulocytes. $B$, Control reaction with the corresponding preimmune IgG. The immunofluorescence staining performed with the affinity-purified anti-IL3 Ab, in combination with an FITC-conjugated secondary Ab, indicates that CiC3aR is expressed in the cytoplasm and on the cell surface of granular and hyaline amoebocytes $(C$ and $E)$. $D$ and $F$, The same fields with Nomarski optics. $G$ and $H$, The fluorescence and Nomarski optic field of the control conducted with the corresponding preimmune Ab. HA, hyaline amoebocyte; GA, granular amoebocyte; MC, morula cell; URG, univacuolar refractile granulocyte. Scale bar, $10 \mu \mathrm{m}$.

The chemotaxis experiments also allowed us to identify the cell types involved in the chemotaxis process. Microscopic analysis of the migrated hemocytes revealed that the chemoattracted cell types were hyaline and granular amoebocytes and univacuolar refractile granulocytes. Small hemocytes that could not be classified were also recovered in the lower chemotaxis chamber.

\section{Discussion}

In a previous paper (26), we demonstrated a chemotactic activity elicited by $\mathrm{C} 3 \mathrm{a}$ in Ciona intestinalis, clearly indicating the presence of a complement-mediated inflammatory pathway in deuterostome invertebrates. Pertussis toxin inhibited this chemotactic activity, suggesting that the receptor molecule mediating the chemotactic effect is $\mathrm{G}$ protein coupled (26). However, the nature of the receptor molecule mediating this chemotaxis was unknown. In the present study, we report the primary structure of a transcript homologous to the mammalian $\mathrm{C} 3 \mathrm{aRs}$ and demonstrate that its product is the membrane molecule interacting with the Ciona $\mathrm{C} 3 \mathrm{a}$ fragment and mediating hemocyte chemotaxis. This information is relevant from an evolutionary point of view because of the phylogenetic position of the ascidians at the base of the vertebrate lineage.

Our Northern blot analysis of the transcripts showed that the $\mathrm{CiC} 3 \mathrm{aR}$ is constitutively expressed in circulating hemocytes and the ovary, heart, and neural complex of the adult animals, as well as in the larval stage. The detection of a single band of $\sim 3.1 \mathrm{~kb}$ in all tissues examined allows us to exclude the presence of different transcripts generated as a result of alternative RNA splicing. The wide $\mathrm{CiC} 3 \mathrm{aR}$ distribution pattern is in agreement with those of mammals (8, 10-13) and fish (20) and is consistent with the role of $\mathrm{C} 3 \mathrm{a}$ as mediator in inflammatory reactions.

The domain structure analysis of the deduced amino acid sequence indicated that $\mathrm{CiC} 3 \mathrm{aR}$, like the mammalian counterparts, is a $\mathrm{G}$ protein-coupled seven-transmembrane receptor.

From the alignment shown in Fig. 5, it is evident that in Ciona the most relevant differences from other $\mathrm{C} 3 \mathrm{aRs}$ involve the carboxyl-terminal tail and the third cytoplasmic loop, which are respectively 105 and 276 aa residues longer than the corresponding regions of vertebrate $\mathrm{C} 3 \mathrm{aRs}$. Although different in size, the $\mathrm{C}$ terminal end of the Ciona cytosolic tail, like those in mammals, contains many serine and threonine residues (eight residues in the segment 808-819) that represent tentative phosphorylation sites.

A further difference between Ciona and the mammalian C3aRs is related to the extracellular amino-terminal sequence, which in Ciona is shorter and lacks the tentative $N$-glycosylation site. In mammals, this site, together with another glycosylation site in the second EL, is thought to be responsible for the carbohydrate content, accounting for the difference between the deduced $(\sim 54 \mathrm{kDa})$ and the SDS-PAGE (83-114 kDa) estimated molecular size (7). In Ciona, the difference between the electrophoretic mobility (98$102 \mathrm{kDa}$ ) and the deduced molecular mass $(95,394 \mathrm{Da})$ is small, even though five presumptive $N$-glycosylation sites have been identified, all within the second EL. 


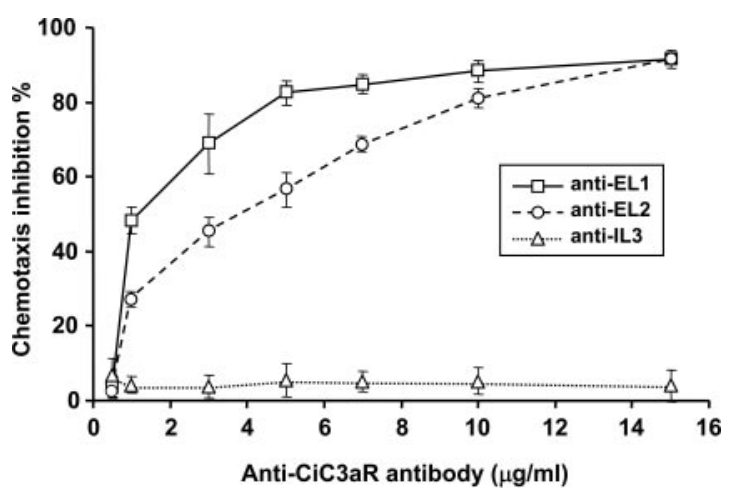

FIGURE 9. Inhibition of hemocyte migration by specific Abs. The 18-aa peptide, $\mathrm{CiC} 3 \mathrm{a}^{59-76}$, representing the $\mathrm{C}$ terminus of the $\mathrm{CiC} 3 \mathrm{a}$ fragment, was used as chemoattractant at the concentration of $10 \mu \mathrm{M}$. Affinitypurified anti-EL1, anti-EL2, or anti-IL3 Ab was used at $0.5-15 \mu \mathrm{g} / \mathrm{ml}$. Control experiments run in parallel using the IgG purified from the corresponding preimmune rabbit serum at the same concentrations did not affect hemocyte migration. Results in the figure are presented as the percentage of inhibition of cell migration and are expressed as the mean \pm SD of five independent experiments.

The most distinctive feature of all the $\mathrm{C} 3 \mathrm{aRs}$ is the length of the second EL, which is generally composed of $\sim 170$ residues, with only two exceptions: one of the two isoforms in the guinea pig, generated by alternative splicing (35 aa residues shorter) (13), and that in the trout $\mathrm{C} 3 \mathrm{aR}$, which is only 36 residues long (20). The length of the second $\mathrm{EL}$ of $\mathrm{CiC} 3 \mathrm{aR}, 162$ aa residues, is comparable to those in mammals. This loop has been shown to be critical for ligand binding involving both sites of the proposed two-site interaction model (15). In Ciona, the situation may be quite different; in fact, although many charged residues are present at the $\mathrm{N}$ and $\mathrm{C}$ termini of the second EL, there is no net negative charge, which has been suggested to be important in the interaction in mammals. However, these differences are not surprising because the $\mathrm{CiC} 3 \mathrm{aR}$ ligand, i.e., CiC3a, also differs from its mammalian homologs (26). These differences at both the ligand and receptor levels could account for a different model of interaction.

To approach this topic, we explored the functional activity of CiC3aR by means of chemotaxis inhibition experiments using Abs against sequences in the first and second extracellular or the third IL. High levels of inhibition of the chemotactic activity $(>90 \%)$ were achieved only with Abs against the ELs of the receptor. As expected, the Ab against the third IL, while not affecting the chemotactic activity, was equally efficient in Western blotting and hemocyte immunostaining. Our results do not allow us to distinguish between the contributions of the first and second ELs to the functional activity. In fact, the Ab inhibitory activity could have resulted either from steric hindrance at the interaction site(s) or by its direct engagement.

A comparative analysis of the sequence of the first EL of the Ciona receptor with those of mammals revealed interesting differences: it is longer and shows a net negative charge that in mammals is a feature of the $\mathrm{N}$ and $\mathrm{C}$ termini of the second EL. This finding could suggest a specific role for the first EL in the functional activity of Ciona.

The phylogenetic analysis we have conducted indicates that $\mathrm{CiC} 3 \mathrm{aR}$ sequence does not cluster with any of the vertebrate $\mathrm{C} 3 \mathrm{aR}$ and $\mathrm{C} 5 \mathrm{aR}$ clades and supports the hypothesis that, if $C 3 a R$ and $C 5 a R$ genes originated from a common ancestor, this event occurred after the emergence of the urochordates. In agreement with this hypothesis is the absence from the Ciona genome of both $\mathrm{C} 5$ and a $C 5 a R$ (38).
In the present study, we have also determined which hemocyte types in the circulating hemolymph express the $\mathrm{C} 3 \mathrm{aR}$. In fact, the immunostaining analysis performed with the anti-CiC3aR Abs showed a clear labeling only of hyaline and granular amoebocytes, which play a crucial role in complement-mediated inflammatory reactions being able to synthesize $\mathrm{C} 3 \mathrm{aR}$ as well as $\mathrm{C} 3$, the precursor of $\mathrm{C} 3 \mathrm{a}$. In addition to these cell types, we also saw migration of the univacuolar refractile granulocytes, which do not express $\mathrm{C} 3 \mathrm{aR}$, toward the chemoattractant in chemotaxis experiments. This cell type has also been shown to be involved in local inflammatory reactions, with its concentration being significantly increased in tunic sections of LPS-injected Ciona (26). This behavior, in the absence of $\mathrm{CiC} 3 \mathrm{aR}$ expression, could be explained by a cooperative effect: amoebocytes, the direct target of $\mathrm{C} 3 \mathrm{a}$, could, in turn, produce a mediator that can activate the univacuolar refractile granulocytes. This situation is somewhat reminiscent of the $\mathrm{C} 3 \mathrm{aR}$ activity described by Daffern et al. (39) in humans. They demonstrated that eosinophils are directly activated by $\mathrm{C} 3 \mathrm{a}$, whereas neutrophils are only indirectly stimulated by $\mathrm{C} 3 \mathrm{a}$ in the presence of eosinophils.

Taken together, our findings provide evidence for the first time of the presence of a functional $\mathrm{C} 3 \mathrm{aR}$ in an invertebrate species. The identification in $C$. intestinalis of both the partners participating in the complement-mediated inflammatory response provides the impetus for further investigating the $\mathrm{C} 3 \mathrm{a}-\mathrm{C} 3 \mathrm{aR}$ interaction at both the molecular and cellular levels.

In this context, a point that we consider relevant concerns the possibility of unraveling the mechanisms that regulate the crosstalk among various hemocyte types during the progression of the inflammatory process. Other points of interest pertain to the identification of the amino acid residues involved in the ligand-receptor recognition and binding, as well as the study of signal transduction and internalization. All this information, in a species at the crossroads between the invertebrate and vertebrate lineages (40), could help to shed light on the evolution of the inflammatory reaction.

\section{Acknowledgments}

We thank Prof. Elio Parisi for the invaluable help in performing the phylogenetic analysis and the Molecular Biology Service of Stazione Zoologica "Anton Dohrn" for assistance in sequencing the CiC3aR. The genomic sequence data were produced by the US Department of Energy Joint Genome Institute (〈www.jgi.doe.gov/〉).

\section{Disclosures}

The authors have no financial conflict of interest.

\section{References}

1. Hugli, T. E. 1989. Chemotaxis. Curr. Opin. Immunol. 2: 19-27.

2. Wetsel, R. A., J. Kildsgaard, and D. L. Haviland. 2000. Complement anaphylatoxins $(\mathrm{C} 3 \mathrm{a}, \mathrm{C} 4 \mathrm{a}, \mathrm{C} 5 \mathrm{a})$ and their receptors $(\mathrm{C} 3 \mathrm{aR}, \mathrm{C} 5 \mathrm{aR} / \mathrm{CD} 88)$ as therapeutic targets in inflammation. In Therapeutics Interventions in the Complement System. J. D. Lambris and V. M. Holers, eds. The Humana Press, New York, pp. $113-153$.

3. Lambris, J. D. 1989. The Third Component of Complement: Chemistry and Biology. Springer-Verlag, Berlin.

4. Song, W-C., M. R. Sarrias, and J. D. Lambris. 2000. Complement and innate immunity. Immunopharmacology 49: 187-198.

5. Hugli, T. E. 1990. Structure and function of C3a anaphylatoxin. Curr. Top. Microbiol. Immunol. 153: 181-208.

6. Kohl, J. 2001. Anaphylatoxins and infectious and non-infectious inflammatory diseases. Mol. Immunol. 38: 175-187.

7. Ember, J. A., M. A. Jagels, and T. E. Hugli. 1998. Characterization of complement anaphylatoxins and their biological responses. In The Human Complement System in Health and Disease. J. E. Volanakis and M. M. Frank, eds. Marcel Dekker, New York, pp. 241-284.

8. Ames, R. S., Y. Li, H. M. Sarau, P. Nuthulaganti, J. J. Foley, C. Ellis, Z. Zeng, K. Su, A. J. Jurewicz, R. P. Hertzberg, et al. 1996. Molecular cloning and characterization of the human anaphylatoxin C3a receptor. J. Biol. Chem. 271: 20231-20234. 
9. Crass, T., U. Raffetseder, U. Martin, M. Grove, A. Klos, J. Kohl, and W. Bautsch 1996. Expression cloning of the human C3a anaphylatoxin receptor (C3aR) from differentiated U-937 cells. Eur. J. Immunol. 26: 1944-1950.

10. Roglic, A., E. R. Prossnitz, S. L. Cavanagh, Z. Pan, A. Zou, and R. D. Ye. 1996. cDNA cloning of a novel $\mathrm{G}$ protein-coupled receptor with a large extracellular loop structure. Biochim. Biophys. Acta 1305: 39-43

11. Hsu, M. H., J. A. Ember, M. Wang, E. R. Prossnitz, T. E. Hugli, and R. D. Ye 1997. Cloning and functional characterization of the mouse C3a anaphylatoxin receptor gene. Immunogenetics 47: 64-72.

12. Tornetta, M. A., J. J. Foley, H. M. Sarau, and R. S. Ames. 1997. The mouse anaphylatoxin $\mathrm{C} 3$ a receptor: molecular cloning, genomic organization, and functional expression. J. Immunol. 158: 5277-5282

13. Fukuoka, Y., J. A. Ember, and T. E. Hugli. 1998. Molecular cloning of two isoforms of the guinea pig $\mathrm{C} 3 \mathrm{a}$ anaphylatoxin receptor: alternative splicing in the large extracellular loop. J. Immunol. 161: 2977-2984.

14. Hollmann, T. J., D. L. Haviland, J. Kildsgaard, K.Watts, and R. A. Wetsel. 1998. Cloning, expression, sequence determination, and chromosome localization of the mouse complement $\mathrm{C} 3 \mathrm{a}$ anaphylatoxin receptor gene. Mol. Immunol. 35: $137-148$.

15. Chao, T-H., J. A. Ember, M. Wang, Y. Bayon, T. E. Hugli, and R. D. Ye. 1999. Role of the second extracellular loop of human $\mathrm{C} 3 \mathrm{a}$ receptor in agonist binding and receptor function. J. Biol. Chem. 274: 9721-9728.

16. Gao, J., H. Choe, D. Bota, P. L. Wright, C. Gerard, and N. P. Gerard. 2003. Sulfation of tyrosine 174 in the human C3a receptor is essential for binding of C3a anaphylatoxin. J. Biol. Chem. 278: 37902-37908.

17. Langkabel, P., J. Zwirner, and M. Oppermann. 1999. Ligand-induced phosphorylation of anaphylatoxin receptors $\mathrm{C} 3 \mathrm{aR}$ and $\mathrm{C} 5 \mathrm{aR}$ is mediated by $\mathrm{G}$ proteincoupled receptor kinases. Eur. J. Immunol. 29: 3035-3046.

18. Settmacher, B., C. Rheinheimer, H. Hamacher, R. S. Ames, A. Wise, L. Jenkinson, D. Bock, M. Schaefer, J. Kohl, and A. Klos. 2003. Structurefunction studies of the C3a-receptor: C-terminal serine and threonine residues which influence receptor internalization and signaling. Eur. J. Immunol. 33 920-927.

19. Sunyer, J. O., H. Boshra, and J. Li. 2005. Evolution of anaphylatoxins, their diversity and novel roles in innate immunity: insights from the study of fish complement. Vet. Immunol. Immunopathol. 108: 77-89.

20. Boshra, H., T. Wang, L. Hove-Madsen, J. Hansen, J. Li, A. Matlapudi, C. J. Secombes, L. Tort, and J. O. Sunyer. 2005. Characterization of a C3a receptor in rainbow trout and Xenopus: the first identification of $\mathrm{C} 3 \mathrm{a}$ receptors in nonmammalian species. J. Immunol. 175: 2427-2437.

21. Nonaka, M., and F. Yoshizaki. 2004. Primitive complement system of invertebrates. Immunol. Rev. 198: 203-215.

22. Nonaka, M., K. Azumi, X. Ji, C. Namikawa-Yamada, M. Sasaki, H. Saiga, A. W. Dodds, H. Sekine, M. K. Homma, M. Matsushita, et al. 1999. Opsonic complement component $\mathrm{C} 3$ in the solitary ascidian, Halocynthia roretzi. J. Immunol. 162: 387-391.

23. Clow, L. A., D. A. Raftos, P. S. Gross, and L. C. Smith. 2004. The sea urchin complement homologue, SpC3, functions as an opsonin. J. Exp. Biol. 207 2147-2155.

24. Zhu, Y., S. Thangamani, B. Ho, and J. L. Ding. 2005. The ancient origin of the complement system. EMBO J. 24: 382-394.
25. Raftos, D. A., J. Robbins, R. A. Newton, and S. V. Nair. 2003. A complement component C3a-like peptide stimulates chemotaxis by hemocytes from an invertebrate chordate-the tunicate, Pyura stolonifera. Comp. Biochem. Physiol. A Physiol. 134: 377-386.

26. Pinto, M. R., C. M. Chinnici, Y. Kimura, D. Melillo, R. Marino, L. A. Spruce, R. De Santis, N. Parrinello, and J. D. Lambris. 2003. CiC3-1a-mediated chemotaxis in the deuterostome invertebrate Ciona intestinalis (Urochordata). J. Immunol. 171: 5521-5528.

27. Sambrook, J., and D. W. Russell. 2001. Molecular Cloning: A Laboratory Manual. Cold Spring Harbor Laboratory Press, Cold Spring Harbor, NY.

28. Feinberg, P., and B. Vogelstein. 1983. A technique for radiolabeling DNA restriction endonuclease fragments to high specific activity. Ann. Biochem. 132: $6-13$.

29. Thompson, J. D., T. J. Gibson, F. Plewniak, F. Jeanmougin, and D. G. Higgins. 1997. The CLUSTAL X windows interface: flexible strategies for multiple sequence alignment aided by quality analysis tools. Nucleic Acids Res. 25: 4876-4882.

30. Guindon, S., and O. Gascuel. 2003. A simple, fast, and accurate algorithm to estimate large phylogenies by maximum likelihood. Syst. Biol. 52: 696-704

31. Jones, D. T., W. R. Taylor, and J. M. Thornton. 1992. The rapid generation of mutation data matrices from protein sequences. Comput. Appl. Biosci. 8: $275-282$.

32. Strimmer, K., and A. von Haeseler. 1996. Quartet puzzling: a quartet maximum likelihood method for reconstructing tree topologies. Mol. Biol. Evol. 13: 964-969.

33. Sahu, A., A. M. Soulika, D. Morikis, L. Spruce, W. T. Moore, and J. D. Lambris 2000. Binding kinetics, structure-activity relationship, and biotransformation of the complement inhibitor Compstatin. J. Immunol. 165: 2491-2499.

34. Satou, Y., L. Yamada, Y. Mochizuki, N. Takatori, T. Kawashima, A. Sasaki, M. Hamaguchi, S. Awazu, K. Yagi, Y. Sasakura, et al. 2002. A cDNA resource from the basal chordate Ciona intestinalis. Genesis 33: 153-154.

35. Blom, N., S. Gammeltoft, and S. Brunak. 1999. Sequence- and structure-based prediction of eukaryotic protein phosphorylation sites. J. Mol. Biol. 294: 1351-1362.

36. Kennelly, P. J., and E. G. Krebs. 1991. Consensus sequences as substrate specificity determinants for protein kinases and protein phosphatases. J. Biol. Chem. 266: $15555-15558$

37. Rowley, A. F., C. P. Rhodes, and N. A. Ratcliffe. 1984. Protochordate leucocytes: a review. Zool. J. Linn. Soc. 80: 283-295.

38. Azumi, K., R. De Santis, A. De Tomaso, I. Rigoutsos, F. Yoshizaki, M. R. Pinto, R. Marino, K. Shida, M. Ikeda, M. Ikeda, et al. 2003. Genomic analysis of immunity in a Urochordate and the emergence of the vertebrate immune system: "waiting for Godot." Immunogenetics 55: 570-581.

39. Daffern, P. J., P. H. Pfeifer, J. A. Ember, and T. E. Hugli. 1995. C3a is a chemotaxin for human eosinophils but not for neutrophils. I. C3a stimulation of neutrophils is secondary to eosinophil activation. J. Exp. Med. 181: 2119-2127.

40. Delsuc, F., H. Brinkmann, D. Chourrout, and H. Philippe. 2006. Tunicates and not cephalochordates are the closest living relatives of vertebrates. Nature 439: 965-968. 